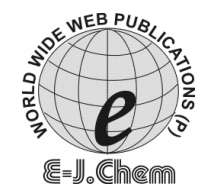

http://www.e-journals.net
ISSN: 0973-4945; CODEN ECJHAO

E-Journal of Chemistry

Vol. 5, No.4, pp. 696-705, October 2008

\title{
Assessment of Underground Water Contamination and Effect of Textile Effluents on Noyyal River Basin In and Around Tiruppur Town, Tamilnadu
}

\author{
A.GEETHA*, P. N. PALANISAMY, P. SIVAKUMAR, \\ P. GANESH KUMAR ${ }^{\#}$ and M. SUJATHA \\ Department of Chemistry, \\ Kongu Engg. College, Erode, Tamilnadu, India - 638052 \\ "Periyar University, Salem, Tamilnadu, India-636 011. \\ ageetha80@yahoo.co.in
}

Received 4 December 2007; Accepted 1 February 2008

\begin{abstract}
A systematic study has been carried out to assess the underground water contamination and the effect of textile effluents on Noyyal River basin in and around Tiruppur Town. Twenty six sampling locations were selected at random and the ground water samples were collected mostly from tube wells at Noyyal River basin in and around Tiruppur area. The samples were analyzed for major physical and chemical water quality parameters like $\mathrm{pH}$, alkalinity, electrical conductivity (EC), total dissolved solids (TDS), total hardness (TH), $\mathrm{Ca}, \mathrm{Mg}, \mathrm{Na}, \mathrm{K}, \mathrm{Cl}^{-} \& \mathrm{SO}_{4}{ }^{2-}$. It was found that the underground water quality was contaminated at few sampling sites due to the industrial discharge of the effluents on to the river or land from the Tiruppur town. The sampling sites namely Orathupalayam, Karuvapalayam, Kulathupalayam, Uttukuli and Kodumanalpudur showed high deviations in total alkalinity, total hardness, $\mathrm{Ca}$, $\mathrm{Mg}$ and chloride concentrations. Hence our study concludes that the underground water quality study in this region shows a constant variation in different parameters in different periods (before and after monsoon). So it is highly important to take periodical monitoring of the underground water quality in this region for our future sustainability.
\end{abstract}

Keywords: Physico-Chemical Characteristics, Ground Water, WHO standard, Tiruppur, Noyyal River.

\section{Introduction}

Tiruppur is a fast growing industrial city in Coimbatore district of Tamilnadu, also known as the 'Banian City' of India. It is located on the bank of the Noyyal River, a tributary of the River Cauvery. The hosiery industry in Tiruppur provides substantial contribution to the economy in the form of income, employment and foreign exchange generation. However, 
the rapid growth of the industry has resulted in serious environmental problems, especially from the bleaching and dyeing units. Hence there is evidence to suggest that these units extract considerable quantity of ground water from the peripheral areas and discharge the effluent without adequate treatment. The discharge of effluents has caused severe pollution of both the surface and ground water in the region and has also contaminated agricultural land. The disposal of untreated wastewater on land and the Noyyal River has affected the quality of surface water, ground water and the soil not only in Tiruppur but in downstream. Available studies clearly prove the accumulation effect of pollution in and around Tiruppur and the downstream stretch of Noyyal exhibit high level of TDS and various salts due to industrial pollution.

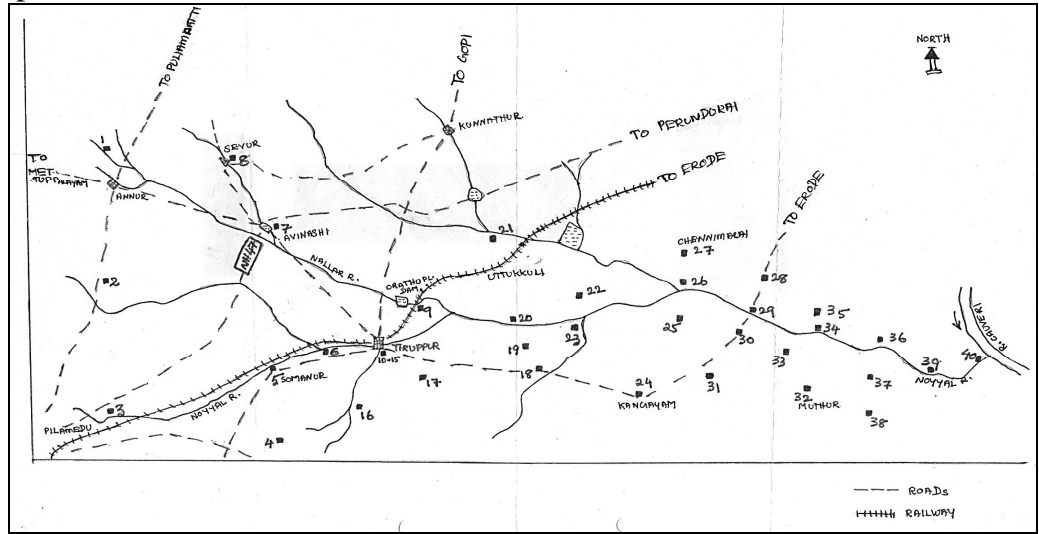

Figure 1. Noyyal River Basin

Ground water contamination is the result of polluted water infiltrating through the soil and rock and eventually reaching the ground water. This process might take many years and might take place at a distance from the well where the contamination is found. Once the ground water is contaminated, it is very difficult to remediate. No doubt that the new technologies will always reduce the pollution level. But the underground water quality in this basin based on various factors, influx of industrial effluent, influx of water through rainfall, soil, agriculture pattern etc., so we can say that by these factors, the underground water quality can be varied qualitatively and quantitatively. It is useful to examine the above highlighted problems in an environmental economic framework in which the quantity and quality of water resources is a major concern. So our objective is to assess the underground water quality in the Noyyal River Basin with special emphasis on Tiruppur town.

\section{Experimental}

During January-February 2007, ground water samples were collected mostly from tube wells at Noyyal River basin in and around Tiruppur area. In some locations where tube wells are not available, water samples were collected from the dug wells. Twenty six sampling locations were selected at random as indicated in the map. (Figure 1). The water samples were collected during the daytime between 9 a.m to 4 p.m. They were collected in one liter plastic bottles. Before sampling, the plastic bottles were cleaned thoroughly to remove all surface contamination, rinsed with double distilled water and dried. The collected samples were properly brought to the laboratory without adding any preservative. Suspended matters if any, in the samples, were removed by filtering through Whatmann filter No.41. Then it is stored in the refrigerator at $40^{\circ} \mathrm{C}$ till the analysis was over. 


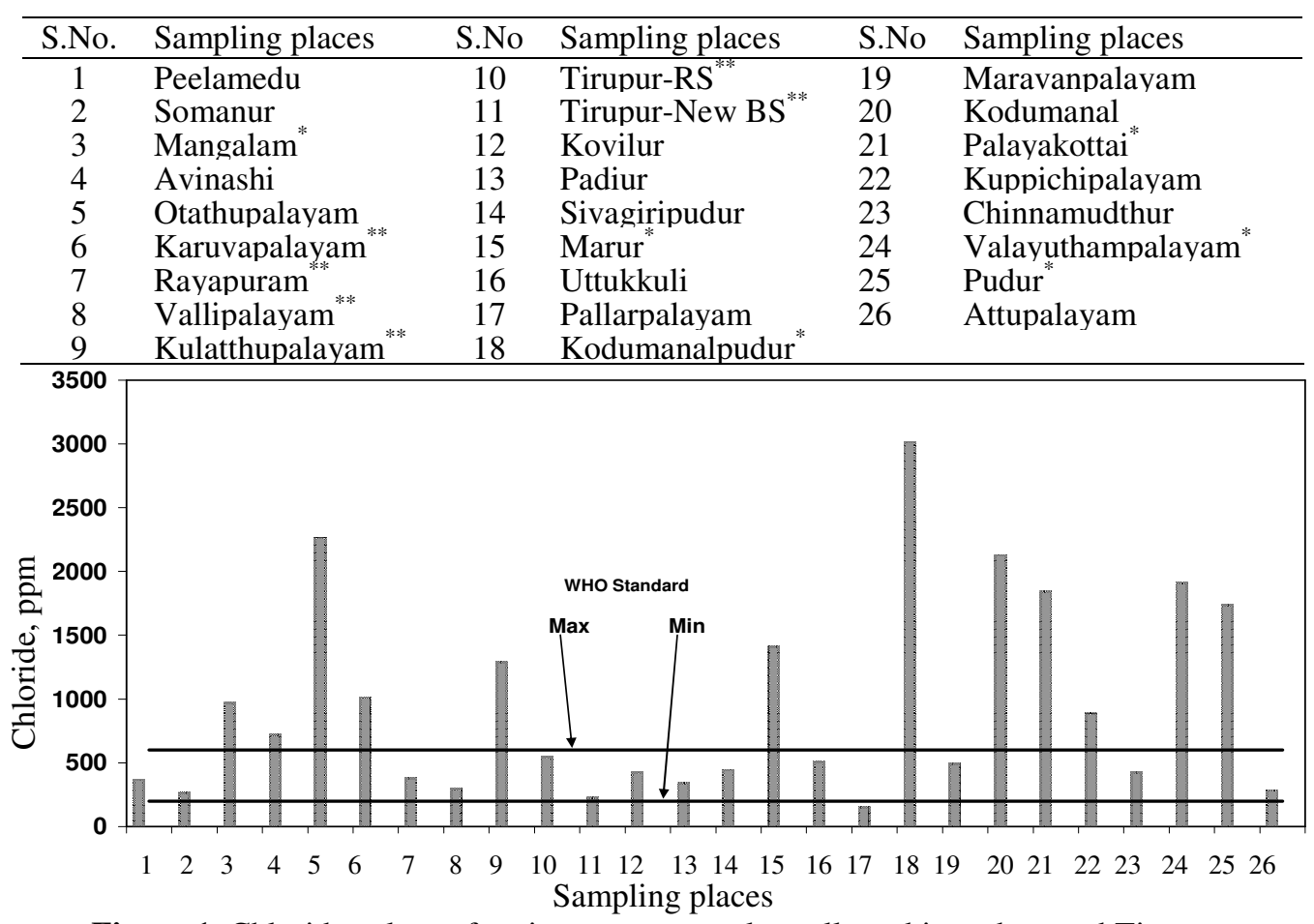

Figure 1. Chloride values of various water samples collected in and around Tiruppur

The samples were analyzed for major physical and chemical water quality parameters like $\mathrm{pH}$, alkalinity, electrical conductivity (EC), total dissolved solids (TDS), total hardness (TH), $\mathrm{Ca}, \mathrm{Mg}, \mathrm{Na}, \mathrm{K}, \mathrm{Cl}^{-} \& \mathrm{SO}_{4}{ }^{2-}$. The analyses were carried out systematically both volumetrically and by instrumental techniques. The procedures were followed from standard books and manual ${ }^{1,2}$ The $\mathrm{pH}$ of the samples was determined using digital $\mathrm{pH}$ meter (Model MK VI).Before measuring the $\mathrm{pH}$ of the sample water, $\mathrm{pH}$ meter standardized using $\mathrm{pH}$ buffer of 4.0 and 9.2. Electrical conductivity was measured using an Elico CM-180 conductivity meter and sulphate by turbidimetric method using a spectronic-20 (Bosch and Lamb,USA).

\section{Results and Discussion}

Various physico chemical parameters were studied and are given in Table 1. Different physical parameters studied are appearance, colour, odour, taste, turbidity, Electrical Conductivity and Total Dissolved Solids. Different chemical parameters studied are $\mathrm{pH}$, alkalinity, total hardness, calcium, magnesium, sodium, potassium, chloride and sulphate. The values were compared with the WHO standard values which are given in the same Table. The results indicate that the quality of water considerably varies from location to location. This wide variation is mainly due to salinity and other dissolved materials from the near by dyeing, bleaching and textile industries in the study area.

Of the physical parameters studied, variations were observed for the parameters -electrical conductivity and total dissolved solids. The standard value for Electrical Conductivity is $1500 \mu \mathrm{S} / \mathrm{cm}$ according to $\mathrm{WHO}^{3}$ Electrical conductivity (EC) of water is a direct function of its total dissolved salts. Hence it is an index to represent the total concentration of soluble salts in water ${ }^{5}$ In our study area, the electrical conductivity varied between 2.7 to $551.6 \mu \mathrm{S} / \mathrm{cm}$. The highest conductivity of $551.6 \mu \mathrm{S} / \mathrm{cm}$ was recorded in the sampling site of Attupalayam was found to exceed the WHO standard. Though the variation is less, it is notable. The reason behind this may be continuous discharge of the chemicals and salts used along with dyes from the industries. 
Table 1. Major physical and chemical water quality parameters of various water samples collected in and around Tiruppur

\begin{tabular}{|c|c|c|c|c|c|c|c|c|c|c|c|c|c|c|}
\hline Sampling Places & 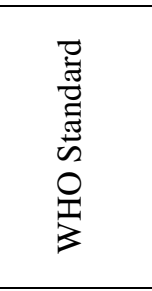 & 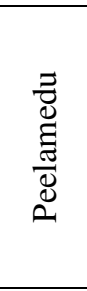 & 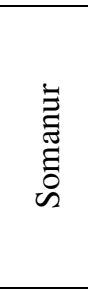 & 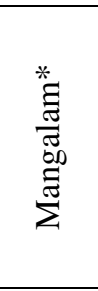 & $\begin{array}{l}: \nexists \\
\stackrel{\Xi}{\Xi} \\
\stackrel{\Xi}{\Xi}\end{array}$ & 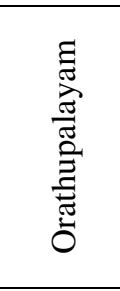 & 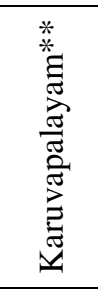 & 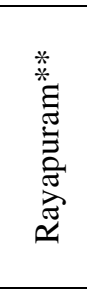 & 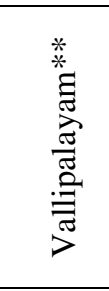 & 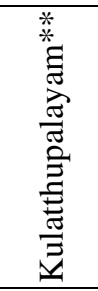 & 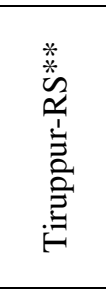 & 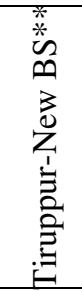 & $\stackrel{\Xi}{\exists}$ & : \\
\hline Water parameters/sample & & 1 & 2 & 3 & 4 & 5 & 6 & 7 & 8 & 9 & 10 & 11 & 12 & 13 \\
\hline$\overline{\mathrm{pH}}$ & $6.5-8.5$ & 7.19 & 7.16 & 8.4 & 7.74 & 7.73 & 7.71 & 7.09 & 7.3 & 7.26 & 7.47 & 6.96 & 7.41 & 7.53 \\
\hline $\mathrm{EC}, \mathrm{mV}$ & - & 44.7 & 10 & 66.7 & 44 & 43.7 & 41.2 & 5.7 & 17.5 & 16.2 & 27 & 2.7 & 25 & 31.1 \\
\hline TDS, ppm & $500-1500$ & 1250 & 735 & 1798 & 820 & 3800 & 2500 & 1350 & 1000 & 2580 & 1588 & 69 & 390 & 820 \\
\hline $\mathrm{DO}, \mathrm{mg} / \mathrm{lit}$ & $5.0-6.0$ & 7.8 & 8.2 & 5.8 & 7.1 & 2 & 5 & 7.3 & 7.3 & 8.5 & 6.5 & 9.8 & 6.1 & 7.2 \\
\hline Sulphate, ppm & 400 & 94.9 & 46.8 & 211.9 & 166.6 & 200 & 223.6 & 117 & 190.5 & 320.2 & 198.9 & Nil & 195 & 63 \\
\hline Cyanide, ppm & - & Nil & Nil & Nil & Nil & 0.0015 & Nil & Nil & Nil & Nil & Nil & Nil & Nil & Nil \\
\hline Chloride, ppm & 1000 & 368 & 265 & 971 & 720 & 2265 & 1013 & 380 & 298 & 1290 & 545 & 226 & 423 & 339 \\
\hline Hydroxide, ppm & - & Nil & Nil & Nil & Nil & Nil & Nil & Nil & Nil & Nil & Nil & Nil & Nil & Nil \\
\hline Carbonate, ppm & - & Nil & Nil & 37 & Nil & 30 & Nil & Nil & Nil & Nil & Nil & Nil & 32 & Nil \\
\hline Bicarbonate, ppm & - & 205 & 210 & 288 & 362 & 595 & 375 & 385 & 360 & 437 & 435 & 322 & 260 & 231 \\
\hline Totalalkalinity, ppm & - & 205 & 210 & 325 & 362 & 625 & 375 & 385 & 360 & 437 & 435 & 322 & 292 & 231 \\
\hline $\mathrm{Ca}$ inCaCO $\mathrm{Ca}_{3}, \mathrm{ppm}$ & 200 & 225 & 325 & 460 & 206 & 350 & 350 & 330 & 235 & 385 & 370 & 360 & 205 & 260 \\
\hline Ca in Calcium Equivalent, ppm & 200 & 90 & 130 & 184 & 81 & 140 & 140 & 132 & 94 & 160 & 148 & 144 & 82 & 104 \\
\hline $\mathrm{Mg}$ in $\mathrm{CaCO}_{3} . \mathrm{ppm}$ & 200 & 235 & 325 & 490 & 304 & 500 & 750 & 280 & 215 & 1006 & 180 & 65 & 325 & 154 \\
\hline Mg in Magnesium equivalent, ppm & 200 & 56 & 78 & 117 & 72 & 120 & 180 & 67 & 51 & 241 & 43 & 15 & 78 & 109 \\
\hline Totalhardness, ppm & 600 & 460 & 650 & 950 & 510 & 850 & 1000 & 610 & 450 & 1391 & 550 & 425 & 520 & 714 \\
\hline Sodium, ppm & - & 102 & 50 & 90 & 93 & 230 & 100 & 230 & 275 & 600 & 126 & 101 & 126 & 73 \\
\hline Potassium, ppm & - & 5 & - & 5 & - & 5 & - & 5 & - & 34 & 13 & 7 & 19 & 14 \\
\hline
\end{tabular}

* Samples are taken very close to the banks of the river ** Samples are taken in and around Tiruppur 


\begin{tabular}{|c|c|c|c|c|c|c|c|c|c|c|c|c|c|c|}
\hline Sampling Places & 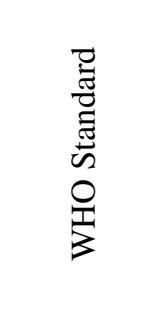 & 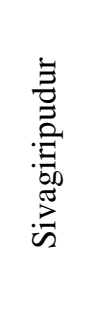 & 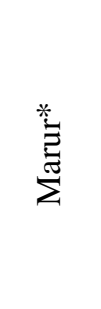 & 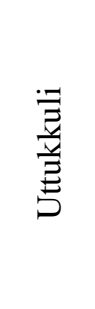 & 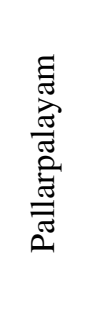 & 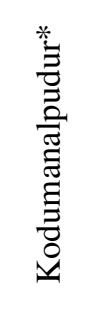 & 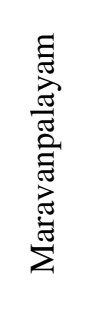 & 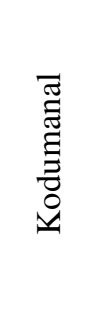 & 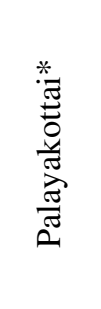 & 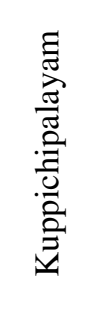 & 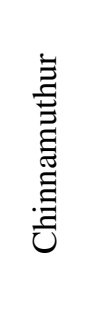 & 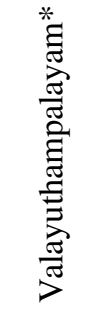 & 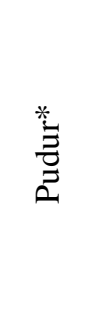 & 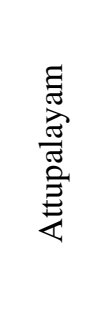 \\
\hline Water parameters/sample & & 14 & 15 & 16 & 17 & 18 & 19 & 20 & 21 & 22 & 23 & 24 & 25 & 26 \\
\hline $\mathrm{pH}$ & $6.5-8.5$ & 7.35 & 7.65 & 7.2 & 7.35 & 7.66 & 7.51 & 7.73 & 7.73 & 7.61 & 8.5 & 7.63 & 7.69 & 7.94 \\
\hline $\mathrm{EC} \mathrm{mV}$ & - & 21.4 & 36.4 & 12.5 & 19.5 & 39.5 & 30.3 & 42.1 & 44.1 & 36.9 & 63.2 & 63.4 & 39.2 & 551.6 \\
\hline TDS, ppm & $500-1500$ & 1220 & 1593 & 915 & 475 & 6080 & 796 & 3810 & 3480 & 823 & 1231 & 2970 & 3114 & 1745 \\
\hline DO mg/lit & $5.0-6.0$ & 6.9 & Nil & 8.9 & 7.1 & Nil & 6.3 & 4.2 & 3 & 6.2 & 6.4 & 4.2 & 2.6 & 8.1 \\
\hline Sulphate, ppm & 400 & 43 & 208 & Nil & 26 & 337 & 123 & 270 & 291 & 56 & 49 & 154 & 236 & 156 \\
\hline Cyanide, ppm & - & Nil & Nil & Nil & Nil & Nil & Nil & Nil & Nil & Nil & Nil & Nil & Nil & Nil \\
\hline Chloride, ppm & 1000 & 442 & 1410 & 510 & 153 & 3012 & 493 & 2127 & 1843 & 886 & 423 & 1914 & 1737 & 283 \\
\hline Hydroxide, ppm & - & Nil & Nil & Nil & NIL & Nil & Nil & Nil & Nil & Nil & Nil & Nil & Nil & Nil \\
\hline Carbonate, ppm & - & Nil & Nil & Nil & 19 & 73 & Nil & 72 & 70 & 63 & Nil & 45 & 27 & 40 \\
\hline Bicarbonate, ppm & - & 236 & 273 & 165 & 174 & 602 & 524 & 565 & 515 & 446 & 441 & 367 & 440 & 438 \\
\hline Total alkalinity, ppm & - & 236 & 273 & 165 & 193 & 675 & 524 & 637 & 585 & 509 & 441 & 412 & 467 & 478 \\
\hline $\mathrm{Ca}$ in $\mathrm{CaCO}_{3}, \mathrm{ppm}$ & 200 & 338 & 325 & 540 & 229 & 725 & 280 & 345 & 350 & 261 & 175 & 260 & 250 & 50 \\
\hline $\begin{array}{l}\mathrm{Ca} \text { in Calcium } \\
\text { Equivalent, ppm }\end{array}$ & 200 & 132 & 130 & 216 & 91 & 290 & 113 & 138 & 140 & 104 & 70 & 104 & 100 & 20 \\
\hline $\mathrm{Mg}$ in $\mathrm{CaCO}_{3}, \mathrm{ppm}$ & 200 & 482 & 450 & 435 & 491 & 1175 & 535 & 480 & 455 & 423 & 41 & 451 & 475 & 175 \\
\hline $\begin{array}{l}\text { Mg in Magnesium } \\
\text { equivalent, ppm }\end{array}$ & 200 & 116 & 108 & 104 & 117 & 282 & 126 & 115 & 109 & 103 & 57 & 108 & 114 & 42 \\
\hline Total hardness, ppm & 600 & 820 & 775 & 975 & 720 & 1900 & 915 & 825 & 805 & 693 & 416 & 710 & 725 & 225 \\
\hline Sodium, ppm & - & 93 & 1250 & 160 & 121 & 1310 & 126 & 1170 & 1115 & 141 & 290 & 985 & 970 & 550 \\
\hline Potassium, ppm & - & 9 & 55 & 20 & 24 & 311 & 22 & 55 & 55 & 21 & 36 & 50 & 50 & 7 \\
\hline
\end{tabular}


The salinity can also be measured in terms of electrical conductivity. Occurance of saline water is more frequent in maximum sampling points. Saline water is generally associated with alluvial aquifers which in general, yield water of higher salinity. Moreover, the bicarbonates contamination from the salt which is mixed with the dyes from the textile industries found to increase the electrical conductivity of the water.

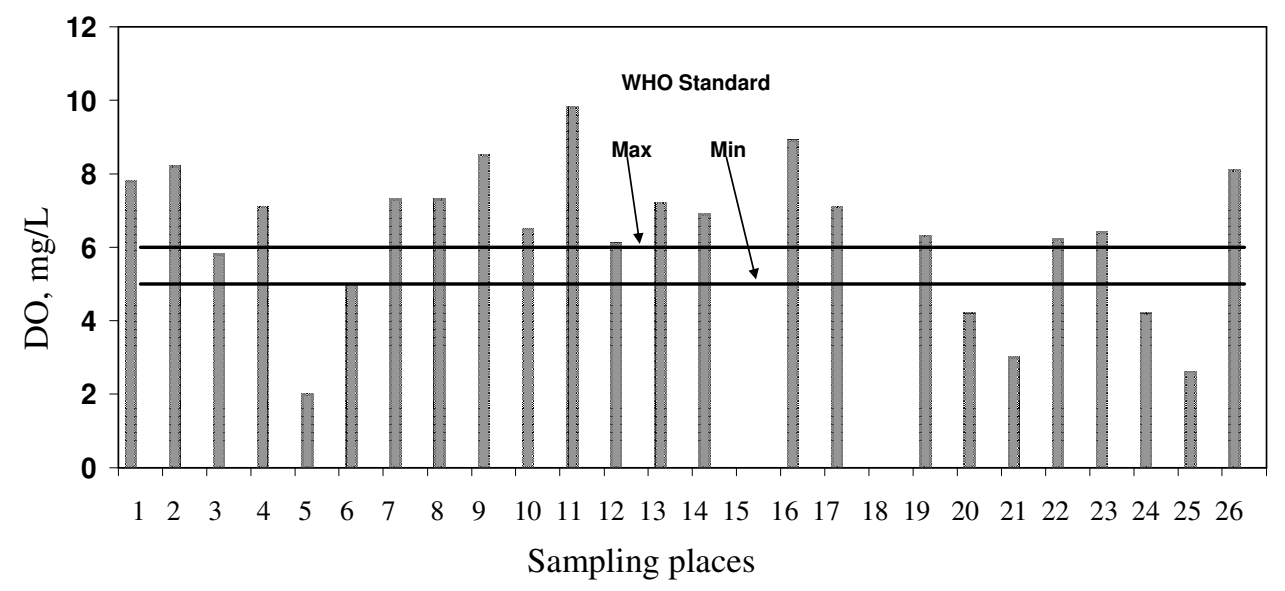

Figure 2. DO values of various water samples collected in and around Tiruppur

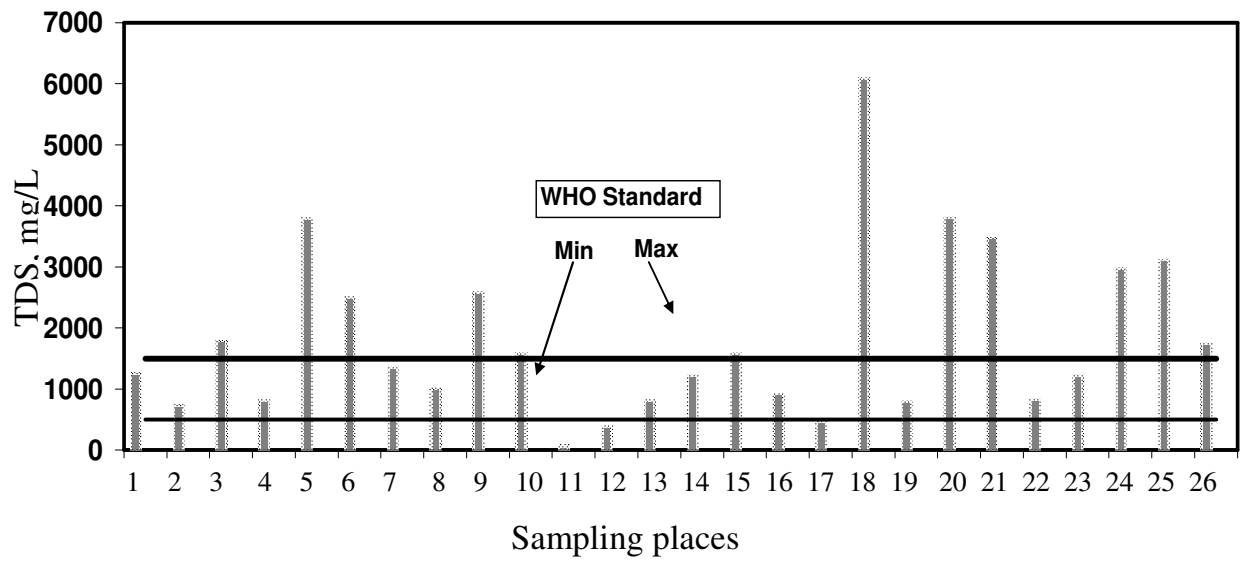

Figure 3. TDS values of various water samples collected in and around Tiruppur.

Out of 26 samples collected in our study area, 12 samples were found to have the highest value of total dissolved solids (TDS) above the permissible limit of 500 to $1500 \mathrm{mg} / \mathrm{L}$. It is worth mentioning here that generally the rocky nature of the earth containing several minerals might be responsible for the high levels of total solids in the groundwater of this region. Moreover the excess TDS values could be due to the dissolved solid waste originated from the discharge of the effluent from the dyeing industries. Particularly the water sample which is collected at Kodumanalpudur showed high TDS value in the range of $6080 \mathrm{mg} / \mathrm{L}$ and it is responsible for ground water pollution. High values of TDS in ground water are generally not harmful to human beings but high concentration of these may affect persons, who are suffering from kidney and heart diseases ${ }^{6}$. Water containing high solid may cause laxative or constipation effects ${ }^{7}$. 


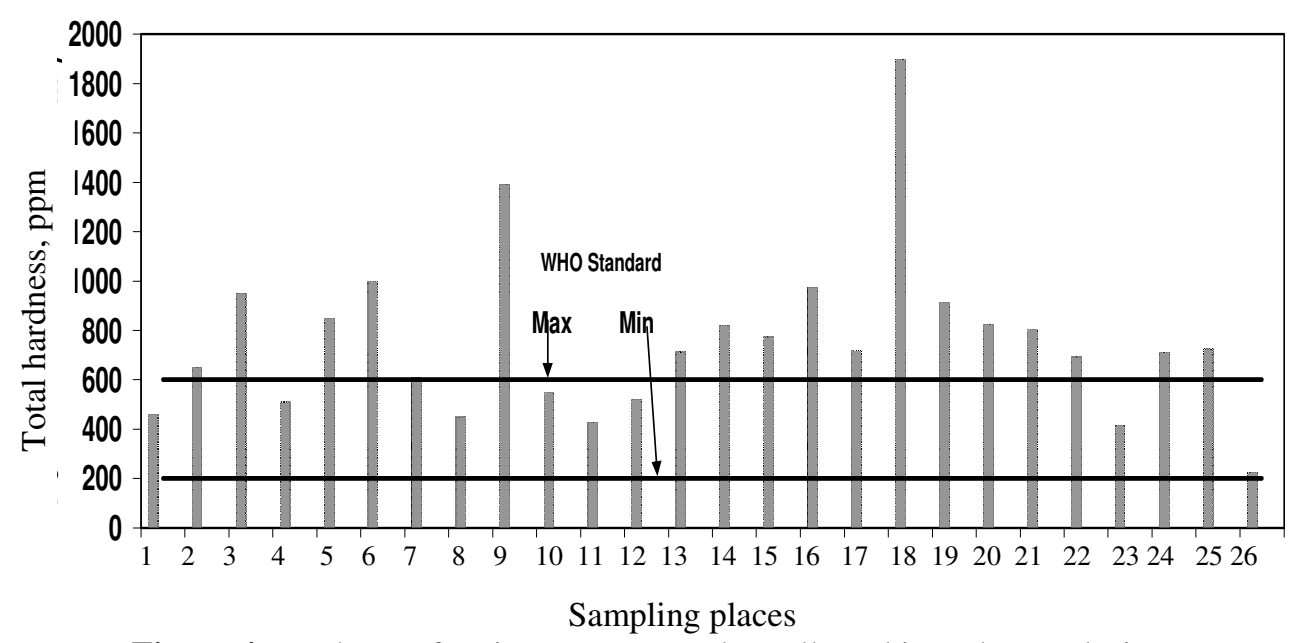

Figure 4. Hardness of various water samples collected in and around Tiruppur.

Among the different chemical parameters analyzed, variations were observed comparing with the standard values for the parameters-sulphate, chloride, $\mathrm{Ca}, \mathrm{Mg}$, and Total Hardness etc.,

The $\mathrm{pH}$ values in the study area vary from 6.96 to 8.5 with the mean value of 7.59 suggesting the alkaline nature of the ground water in the study area. Thus a slight variation was recorded due to the alkalinity of effluent. However the $\mathrm{pH}$ value of all the samples falls within the permissible limit ${ }^{8,9}$.

Alkalinity of water is the capacity to neutralize acidic nature and the presence of carbonates, bicarbonates and hydroxides are the main cause of alkalinity in natural waters. The alkalinity values in the study area found to vary from 165 to $675 \mathrm{mg} / \mathrm{L}$. The alkalinity of ground water samples in Kodumanalpudur, Kodumanal \& Orathupalayam found to be greater than $600 \mathrm{mg} / \mathrm{L}$. Alkalinity around $150 \mathrm{mg} / \mathrm{L}$ has been found conductive to higher productivity of water bodies ${ }^{10}$.

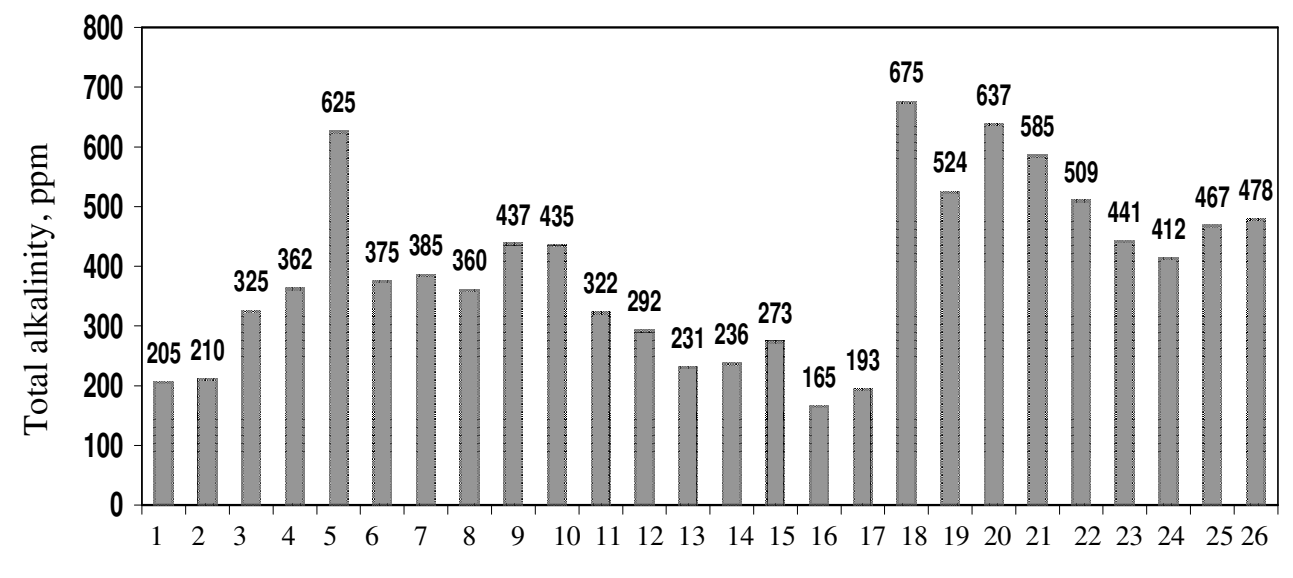

Sampling places

Figure 5. Alkalinity of various water samples collected in and around Tiruppur

Of the physical parameters studied, variations were observed for the parameters electrical conductivity and total dissolved solids. The standard value for Electrical Conductivity is $1500 \mu \mathrm{S} / \mathrm{cm}$ according to WHO. ${ }^{3}$ Electrical conductivity (EC) of water is a direct function of its total dissolved salts ${ }^{4}$. Hence it is an index to represent the total 
concentration of soluble salts in water ${ }^{5}$. In our study area, the electrical conductivity varied between 2.7 to $551.6 \mu \mathrm{S} / \mathrm{cm}$. The highest conductivity of $551.6 \mu \mathrm{S} / \mathrm{cm}$ was recorded in the sampling site of Attupalayam was found to exceed the WHO standard. Though the variation is less, it is notable. The reason behind this may be continuous discharge of the chemicals and salts used along with dyes from the industries.

Based on the EC values, the ground water quality can be classified as poor, medium and good. The water samples collected in the sampling sites of Peelamedu, Mangalam, Avinashi, Orathupalayam, Karuvapalayam, Tiruppur-RS, Padiyur, Marur, Kodumanalpudur, Maravanpalayam, Kodumanal, Palayakottai, Kuppichipalayam, Chinnamuthur, Velayutahmpalayam, Pudur and Attupalayam showed a very high value of electrical conductivity in the range of 27 to $66.7 \mu \mathrm{S} / \mathrm{cm}$ and hence they are said to be of poor quality. Water samples collected in the sampling sites namely Vallipalayam, Kulatthupalayam, Kovilur, Sivagiripudur, Uttukkuli and Pallarpalayam showed value of electrical conductivity in the range of 10 to $25 \mu \mathrm{S} / \mathrm{cm}$ and they are said to be of medium quality. Water samples collected in the sampling sites of Somanur, Rayapuram and Tiruppur New BS are found to have very low electrical conductivity in the range of 1 to $10 \mu \mathrm{S} / \mathrm{cm}$ and they are said to be of good quality.

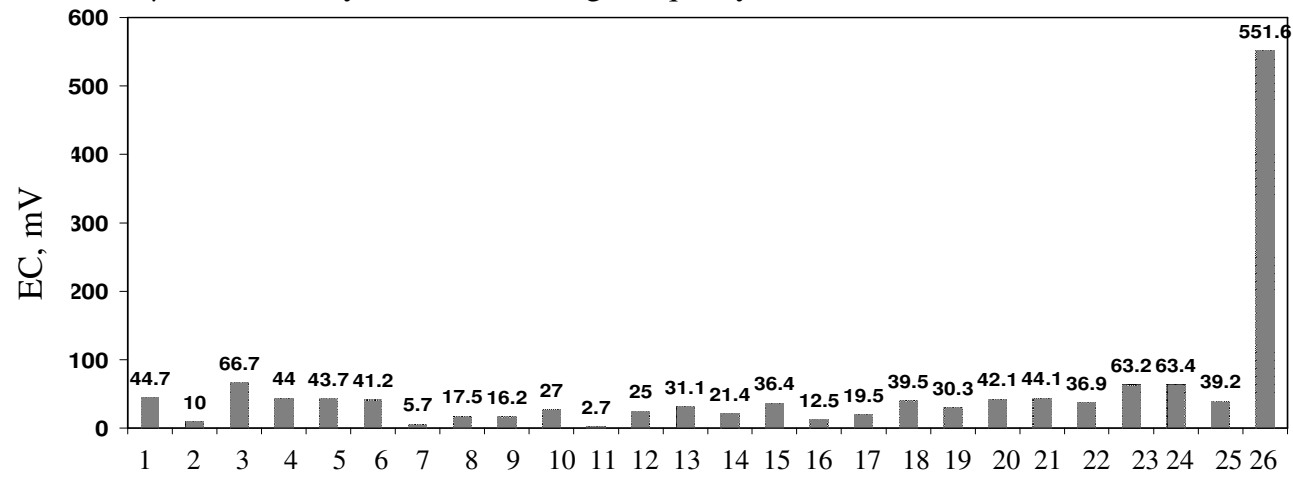

Figure 6. EC values of various water samples collected in and around Tiruppur.

The total hardness (TH) in the study area found to vary from 225 to $1900 \mathrm{mg} / \mathrm{L}$ with mean value of 753 . Only one sample were found within desirable limit of $300 \mathrm{mg} / \mathrm{L}, 40 \%$ samples were found within maximum permissible limit of $600 \mathrm{mg} / \mathrm{L}$ and about $60 \%$ samples crossed the maximum permissible limit. Among this the water samples collected at Kulathupalayam and Kodumanalpudur was found to be very higher than the permissible limit. It clearly indicates that the effluent has affected the ground water. Though it affects the ground water, it has no adverse effect on human health. In most of the samples, total hardness value exceeds the tolerance limit; this may be due to industrial discharge of the effluents on to the land.

Chloride is a widely distributed element in all types of rocks in one or the other form. Its affinity towards sodium is high. Therefore, its concentration is high in ground waters, where the temperature is high and rainfall is less. Soil porosity and permeability also has a key role in building up the chlorides concentration ${ }^{11}$. The chloride concentration varied from 153 to $3012 \mathrm{mg} / \mathrm{L}$ in the study area. The samples collected at Kodumanalpudur \& Orathupalayam was found to have high chloride concentration of $3012 \& 2265 \mathrm{mg} / \mathrm{L}$. It may be due to the continuous usage of chloride salts in the industries preferably in dyeing and bleaching. Most of the other samples were found to possess excess chloride concentration due to the presence of soluble chlorides from rocks ${ }^{12}$. 
Calcium, magnesium and total hardness in the water are inter-related. An important source of calcium is the dissolution of small quantities of carbonate compounds from industries. Calcium concentrations varied from 20 to $290 \mathrm{mg} / \mathrm{L}$ in the study area. However, the calcium in $\mathrm{Ca}$ equivalent value falls within the permissible limit except the two samples collected at Kodumanalpudur \& Uttukuli. The value was found to be 290 and $216 \mathrm{mg} / \mathrm{L}$ respectively.

Magnesium usually occurs in lesser concentration than calcium due to the fact that the dissolution of magnesium rich minerals is slow process and that of calcium is more abundant in the earth's crust. ${ }^{13}$ Magnesium concentrations varied from 15 to $282 \mathrm{mg} / \mathrm{L}$ in the study area. All values lies within the desirable limit except few samples. The desirable magnesium value for drinking water prescribed by WHO is $150 \mathrm{mg} / \mathrm{L}$. The water samples collected from Karuvapalayam, Kalatthupalayam and Kodumanalpudur was found to have 180, 241 \& $282 \mathrm{mg} / \mathrm{L}$ of $\mathrm{Mg}$ concentration respectively which beyond the limit of WHO value.

Sodium occurs as a major cation in water samples. The concentration of sodium in the study area ranged from 50 to $1310 \mathrm{mg} / \mathrm{L}$ with the mean value of $403 \mathrm{mg} / \mathrm{L}$. The sodium concentration more than $50 \mathrm{mg} / \mathrm{L}$ makes the water unsuitable for domestic use. The sodium concentration was observed to be higher at few sampling sites namely Marur, Kodumanalpudur, Kodumanal and Palayakottai.

Potassium is though a minor element in ground water, the concentration of potassium in ground water varied from 5 to $311 \mathrm{mg} / \mathrm{L}$ with the mean value of $38 \mathrm{mg} / \mathrm{L}$. Its abnormal concentration is found in the sampling site of Vallipalayam.

No cyanide was identified even in trace amounts. This may be due to the absence of major cyanide based chemical industries in our focus area. The sulphate concentration varied from 26 to $337 \mathrm{mg} / \mathrm{L}$ in the study area did not show any remarkable deviation and were very much within the tolerance limit.

17 samples out of 26 samples tested found to have DO value greater than the permissible limits. This may be attributed to the seepage of effluents from the industries in to the ground water. But this value does not have any impact since it is not directly consumed by aquatic animals ${ }^{14}$.

On the basis of the obtained values for various physico-chemical parameters, the sampling sites namely Orathupalayam, Karuvapalayam, Kulathupalayam, Uttukuli and Kodumanalpudur showed high deviations in total alkalinity, total hardness, $\mathrm{Ca}, \mathrm{Mg}$ and chloride concentrations. Only slight variations were recorded in alkalinity, total hardness and total dissolved solids for other samples. High concentrations of sodium, potassium and chlorides were observed at few sampling places but they were not at any risk conditions. Sulphate and Cyanide values for all the water samples did not show any remarkable deviation and were very much within the tolerance limit. Few samples were reported with higher DO values than the permissible limits, but this value does not have any impact for the underground water.

\section{Conclusions}

Among 26 water samples analyzed, except few samples, all other samples were found to have the values according to the standard values prescribed by WHO for all the parameters. It was also found that the underground water quality was contaminated at few sampling sites due to the industrial discharge of the effluents on to the river or land from the Tiruppur town. It is because of soil porosity, permeability and also the rocks nature of those particular sampling places. From the analyses, it will be logical to say that the textile effluent from the 
industrial area of Tiruppur town has its impact on the quality of underground water in some sampling sites of our study area. Hence the results suggest that the underground water may be altered in future due to excess population, urbanization and rapid industrialization of this catchment area. Therefore, there should be proper disposal of solid slurry after treatment as well as recycling of wastewater along with periodical monitoring of the underground water. It is some of relevant ingredients of management strategies for Tiruppur area.

Hence our study concludes that the underground water quality study in this region shows a constant variation in different parameters in different periods (before and after monsoon). So it is highly important to take periodical monitoring of the underground water quality in this region for our future sustainability.

\section{References}

1. Sunitha Hooda and Sumanjee Kaur, cited in Laboratory Manual for Environmental Chemistry, Edited by S Chand \& Company Limited, Ram Nagar, New Delhi, 1999.

2. Lab Manual for Water and Wastewater analysis, Edited by Tamilnadu Water Supply \& Drainage Board, Chennai.

3. Sunitha V, Sudarshan V and Rajeswara Reddy B, Poll Res, 2005, 24(1), 217.

4. Harilal C C, Hashim A, Arun P R and Baji S, Journal of Ecology, Environment and Conservation., 2004, 10(2), 187-192.

5. Purandara B K, Varadarajan N and Jayashree K, Poll Res., 2003, 22(2),189.

6. Gupta S, Kumar A, Ojha C K and Singh G, Journal of Environmental Science \& Engineering. 2004, 46(1), 74-78.

7. Kumaraswamy N, Journal of Pollution Research., 1999, 10(1), 13-20.

8. WHO, World Health Organisation, International Standards for Drinking Water, Geneva, Swtzerland, 1992.

9. BIS: 3025, Method of sampling and test (physical and chemical) for water and waste water, Part-44, Biochemical Oxygen Demand (BOD), First Revision, 1993,1-2.

10. Ball R C, Fertilization of lake, good or bad, Michigen, Conserv. 1994, 7-14.

11. Chanda D K, Hydrology Journal, 1999, 7(5), 431-439.

12. Jain C K and Bhatia K K S, Physico-chemical analysis of water and wastewater, U.M-26, National Institute of Hydrology, Roorkee,1987-88.

13. Varadarajan N and Purandara B K, Environment and conservation., 2003, 9(3), 253- 262.

14. Palanisamy P N, Geetha A, Sujatha M, Sivakumar P and Karunakaran K, E-J. Chem., 2007, 4(3), 434-439. 


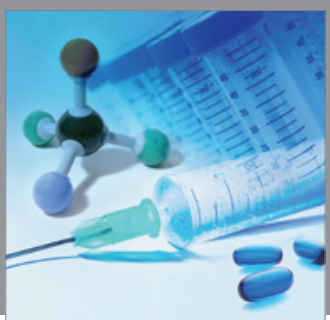

International Journal of

Medicinal Chemistry

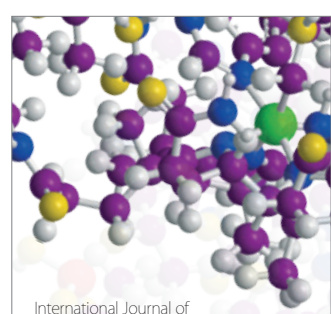

Carbohydrate Chemistry

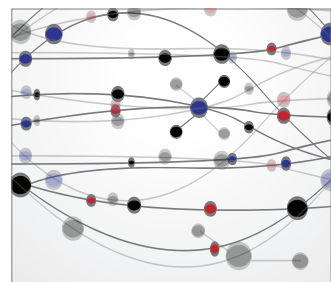

The Scientific World Journal
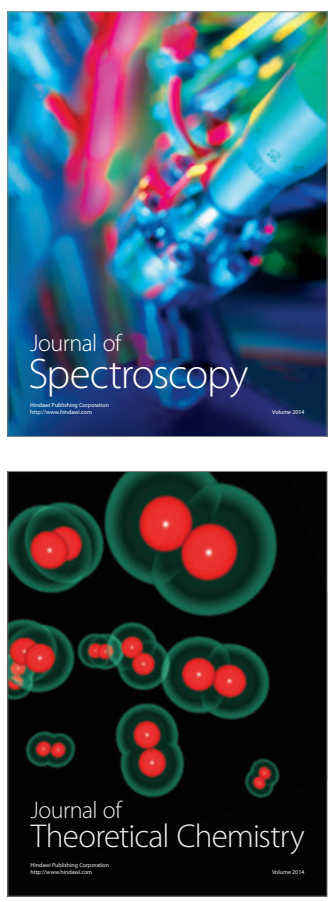
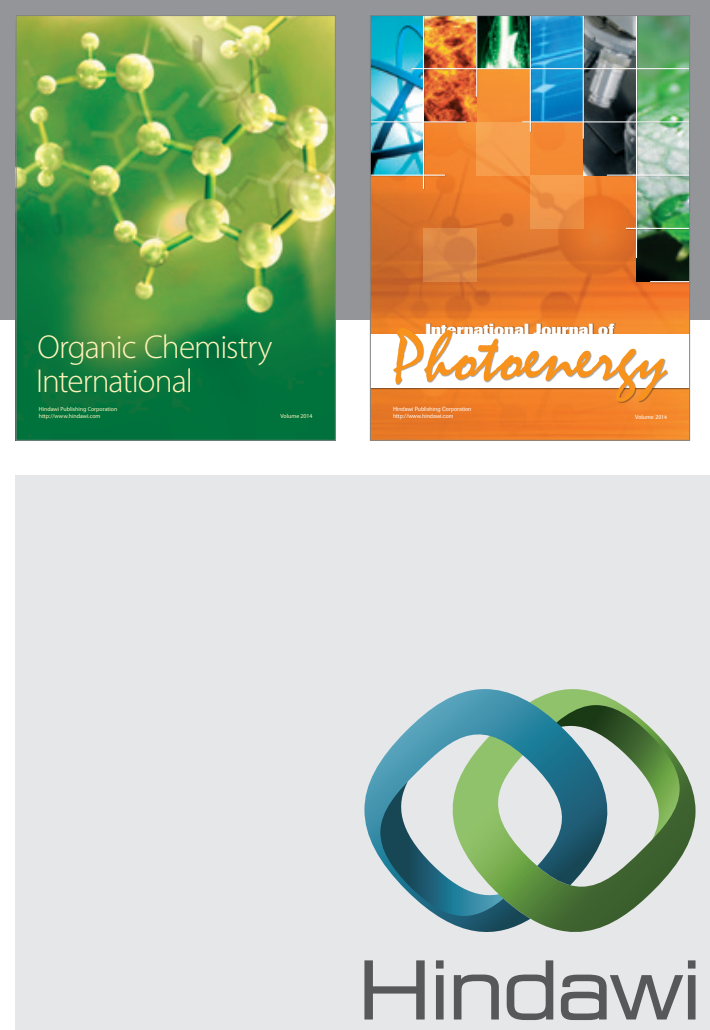

Submit your manuscripts at

http://www.hindawi.com
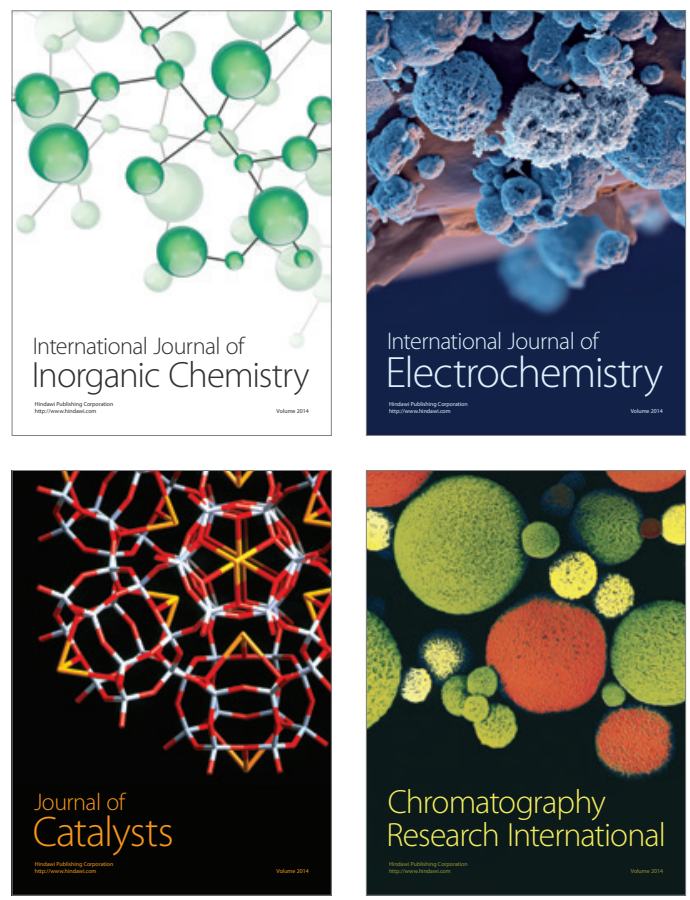
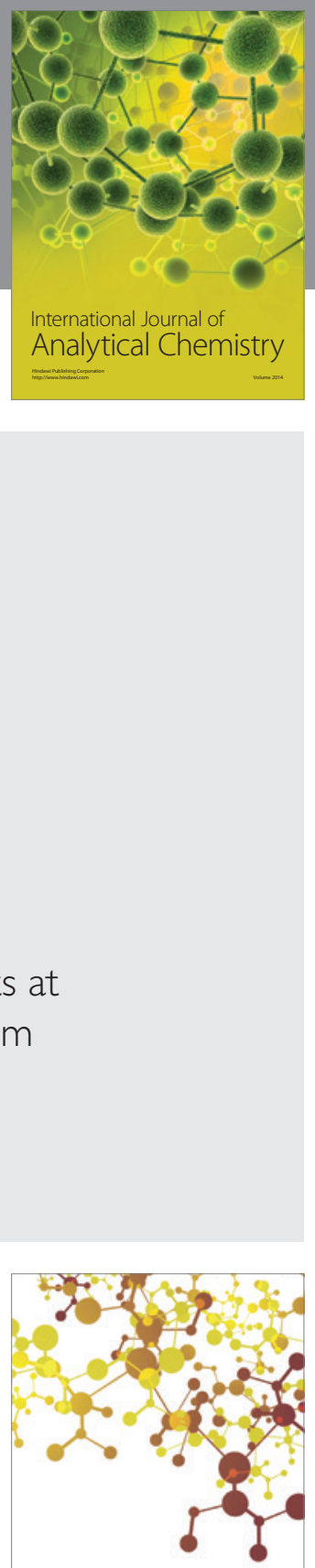

Journal of

Applied Chemistry
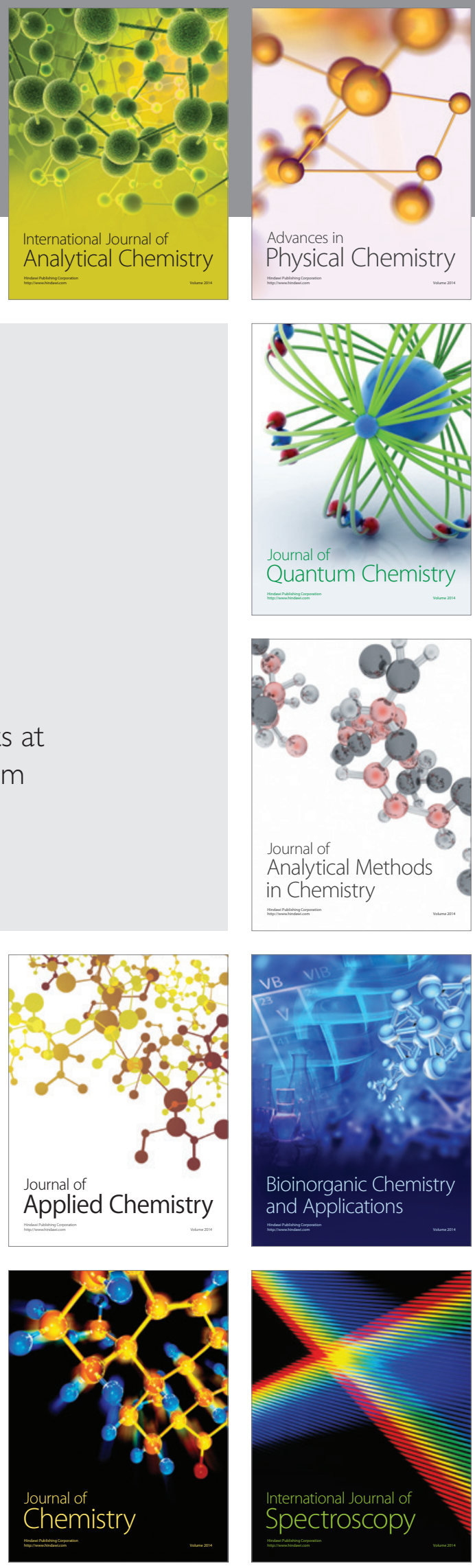